ARTICLE

Received 15 Sep 2013 | Accepted 28 Aug 2014 | Published 24 Oct $2014 \quad$ DOl: 10.1038/ncomms6095

\title{
Subduction of fracture zones controls mantle melting and geochemical signature above slabs
}

Vlad C. Manea1, William P. Leeman², Taras Gerya ${ }^{3,4}$, Marina Manea \& Guizhi Zhu ${ }^{3}$

For some volcanic arcs, the geochemistry of volcanic rocks erupting above subducted oceanic fracture zones is consistent with higher than normal fluid inputs to arc magma sources. Here we use enrichment of boron $(\mathrm{B} / \mathrm{Zr})$ in volcanic arc lavas as a proxy to evaluate relative alongstrike inputs of slab-derived fluids in the Aleutian, Andean, Cascades and Trans-Mexican arcs. Significant B/Zr spikes coincide with subduction of prominent fracture zones in the relatively cool Aleutian and Andean subduction zones where fracture zone subduction locally enhances fluid introduction beneath volcanic arcs. Geodynamic models of subduction have not previously considered how fracture zones may influence the melt and fluid distribution above slabs. Using high-resolution three-dimensional coupled petrological-thermomechanical numerical simulations of subduction, we show that enhanced production of slab-derived fluids and mantle wedge melts concentrate in areas where fracture zones are subducted, resulting in significant along-arc variability in magma source compositions and processes.

\footnotetext{
${ }^{1}$ Computational Geodynamics Laboratory, Centro de Geociencias, Universidad Nacional Autónoma de México, Juriquilla, C.P. 76230 Querétaro, Mexico.

${ }^{2}$ Department of Earth Science, Rice University, 642 Cumbre Vista, Santa Fe, New Mexico 87501, USA. ${ }^{3}$ Department of Geosciences, Swiss Federal Institute of Technology (ETH-Zurich), CH-8092 Zurich, Switzerland. ${ }^{4}$ Geology Department, Moscow State University, 119899 Moscow, Russia. Correspondence and requests for materials should be addressed to V.C.M. (email: vlad@geociencias.unam.mx).
} 
O ceanic fracture zones are born where spreading centres are offset, creating strong gradients in oceanic floor age and vertical offsets in the oceanic lithosphere ${ }^{1}$. Whether or not fracture zones are weaker than normal oceanic lithosphere is a subject of debate ${ }^{2-6}$. However, several lines of evidence, such as tectonic uplift ${ }^{4}$ and localized volcanic activity distributed along fracture zones ${ }^{5}$, suggest that oceanic fracture zones may indeed be zones of weakness. Dynamic models of Pacific fracture zones ${ }^{6}$ show that they need to be mechanically weak (yield strength $<10 \mathrm{MPa}$ ) in order to have synthetic gravity offsets consistent with the observations. Other evidence indicative of fracture zone weakness is the statistically prevalent occurrence of intraplate oceanic earthquakes near fracture zones ${ }^{7}$. In addition, fracture zones provide conduits for seawater infiltration where peridotites locally may be exposed to intense hydrothermal alteration producing serpentinites. Serpentinites have low mechanical strength compared with unaltered peridotite ${ }^{8}$, and laboratory experiments show that, at depths of approximately $30-100 \mathrm{~km}$, serpentine is weaker than most other mantle minerals (for example, pyroxene, plagioclase, and wet and dry olivine ${ }^{9}$ ). Deformation experiments show that the presence of a small amount of serpentine $(\sim 10 \%)$ reduces drastically the strength of an altered peridotite to that of pure serpentinite ${ }^{8}$. Serpentinites are commonly associated with major fracture zones on the Juan de Fuca, Pacific, Cocos and Nazca plates ${ }^{10-14}$, and potentially create zones of weakness in the oceanic lithosphere ${ }^{15}$ to depths of $20 \mathrm{~km}$ or more below the oceanic Moho ${ }^{16}$.

There is wide consensus among researchers that slab-derived fluids exert significant influence on partial melting of the mantle wedge beneath volcanic arcs. Moreover, seismic studies are consistent with local addition of up to $2 \mathrm{wt} \%$ of slab-derived hydrous fluids to mantle wedge domains ${ }^{17}$. Compared with regions where 'normal' oceanic lithosphere is subducted, the presence of fracture zones will likely deliver anomalous volumes ${ }^{18}$ of water-rich serpentinite to depths of $100 \mathrm{~km}$ or more ${ }^{19}$, and thus augment the flux of slab-derived fluids to the overlying mantle. However, there is no clear view on the effect, if any, of fracture zone subduction on melt distribution below volcanic arcs. As volcanic arc lavas generally carry signals of hydrous fluids, they can be used as probes to assess spatial variations in fluxes of slab-derived components and how these might correlate with along-strike heterogeneities in downgoing subducting plates.

There is compelling evidence that compositions of volcanic arc magmas may be strongly influenced by the amount and nature of aqueous fluids released by the subducting plates ${ }^{20-22}$. A variety of geologic and petrologic observations suggest that lateral variations in chemical fluxes and processes of magma generation in volcanic arcs could reflect along-strike structural and compositional variations (for example, due to the presence of fracture zones) in downgoing subducting plates. For example, Aleutian arc volcanoes (that is, Seguam and Yunaska) situated above the subducted Amlia fracture zone (Fig. 1) are characterized by unusual enrichment of the fluid-mobile element boron ${ }^{23-25}$. High ratios of $\mathrm{B} / \mathrm{La}$ and $\mathrm{B} / \mathrm{Be}$ in lavas from this region are attributed to modification of the magma source(s) by unusually high fluxes of aqueous fluids presumably released from serpentine-rich rocks in the downgoing slab. Another example is Mount Shasta, the largest stratovolcano of the Cascades range. The presence of melt inclusions (MIs) with up to nearly $4 \% \mathrm{H}_{2} \mathrm{O}$ (ref. 26) in unusual high- $\mathrm{Mg}$ andesites with elevated $\mathrm{Sr} / \mathrm{Y}$ and $\delta^{18} \mathrm{O}$ (refs 27,28 ), and relatively high volcanic output in this sector of the arc have been attributed to subduction of the Blanco fracture zone beneath this area. Augmented fluid fluxes from fracture zone serpentinites ${ }^{10,29,30}$ could account for enhanced melt productivity and for some of the anomalous geochemical features. Similarly, water-rich magmas from Colima and El Chichon volcanoes in the Trans-Mexican Volcanic Belt ${ }^{31}$, and from Nevado de Longaví (high $\mathrm{Ba} / \mathrm{Th}, \mathrm{Sr} / \mathrm{Y}$ and $\mathrm{La} / \mathrm{Yb}$ ratios $^{11,32}$ ), Villarrica and Llaima (high $\mathrm{U} / \mathrm{Th}$ and $\mathrm{Pb} / \mathrm{Ce}$ ratios $^{33}$ ) volcanoes in the Andean Southern Volcanic Zone ${ }^{11}$ could reflect locally anomalous fluxes of slab-derived fluids associated with subduction of the Rivera, Tehuantepec ${ }^{14}$, Mocha ${ }^{11}$ and Valdivia fracture zones, respectively (Fig. 1).

Here, we present evidence that anomalous enrichment of B (B/ $\mathrm{Zr}$ ratio) and other fluid-mobile elements in arc magma sources in several regions strongly correlate with subduction of major fracture zones (Fig. 1), but not in the relatively warm Cascadia and Mexican subduction zones. We infer that fracture zone subduction locally enhances fluid introduction beneath volcanic arcs, but that retention of slab fluids to sub-arc depths depends on subduction zone thermal gradient and approaches negligible efficiency in the warmest subduction zones. We then use threedimensional high-resolution coupled petrological-thermomechanical numerical models to simulate the physical processes associated with subduction of fracture zones (more details can be found in Methods and Supplementary Table 1). The numeric models robustly reveal that partial melts and fluids focus above the slab in areas where fracture zones are subducted.

\section{Results}

Along-arc geochemical variations. To further assess variations in slab-derived fluid inputs to the sub-arc mantle wedge, we consider regional geochemical variations in lavas from the aforementioned volcanic arcs. Unfortunately, direct measurements of water fluxes are poorly constrained in a regional sense owing to relatively sparse measurements of water contents in MIs, as well as the difficulty in relating such measurements directly to slab inputs (see Supplementary Note 1). Owing to the high solubility of B in aqueous solutions ( $c f$. ref. 34), this element can serve as a useful proxy for infiltration of slab-derived fluids, and sufficient data are now available for boron contents in arc lavas to evaluate regional patterns in fluid inputs for some arcs. In contrast to intraplate volcanic rocks (for example, mid-ocean ridge or ocean island basalts), arc lavas commonly exhibit selective enrichment of $\mathrm{B}$ relative to other highly incompatible elements such as $\mathrm{Nb}$ or $\mathrm{Zr}$ (cf. ref. 35). Elevated $\mathrm{B} / \mathrm{Nb}$ or $\mathrm{B} / \mathrm{Zr}$ ratios in arc lavas can be attributed to inputs to the mantle wedge of aqueous fluids released by devolatilization of subducted materials ${ }^{36}$. Importantly, because all of these elements $(\mathrm{B}, \mathrm{Zr}, \mathrm{Nb}, \mathrm{La}, \mathrm{Ba}$ and in general all highly incompatible elements) partition similarly into silicate melts ( $c f$. refs 37,38), selective enrichment of B in magma sources cannot plausibly be attributed to melt-forming processes or to subsequent magma differentiation processes. Moreover, a slab origin is strongly implicated because B-enrichment in several arcs is strongly correlated with that of ${ }^{10} \mathrm{Be}$, which is uniquely added to the mantle via subduction ${ }^{39}$.

For convenience, and because high-quality data for $\mathrm{Zr}$ are more readily available than for $\mathrm{Nb}$, here we mainly employ the $\mathrm{B} / \mathrm{Zr}$ ratio as an indicator of relative variations in fluid inputs beneath each of the volcanic arcs considered; this ratio also generally correlates with measured water content in MIs from arc lavas (cf. Supplementary Fig. 1 and Supplementary Note 1). Where available, $\mathrm{B} / \mathrm{Nb}, \mathrm{B} / \mathrm{La}$ and similar ratios mimic the trends defined by $\mathrm{B} / \mathrm{Zr}$ (Fig. 2). Along-strike variations in B-enrichment can be explained by fluctuations in the B inventory of the slab as well as differences in the thermal gradient, hence devolatilization history of the subducting slab. It is likely that these factors are relatively consistent for arc segments where the subducting slab comprises 'normal' or uncomplicated oceanic lithosphere of similar age and thermal maturity. Conversely, along-strike variations in 


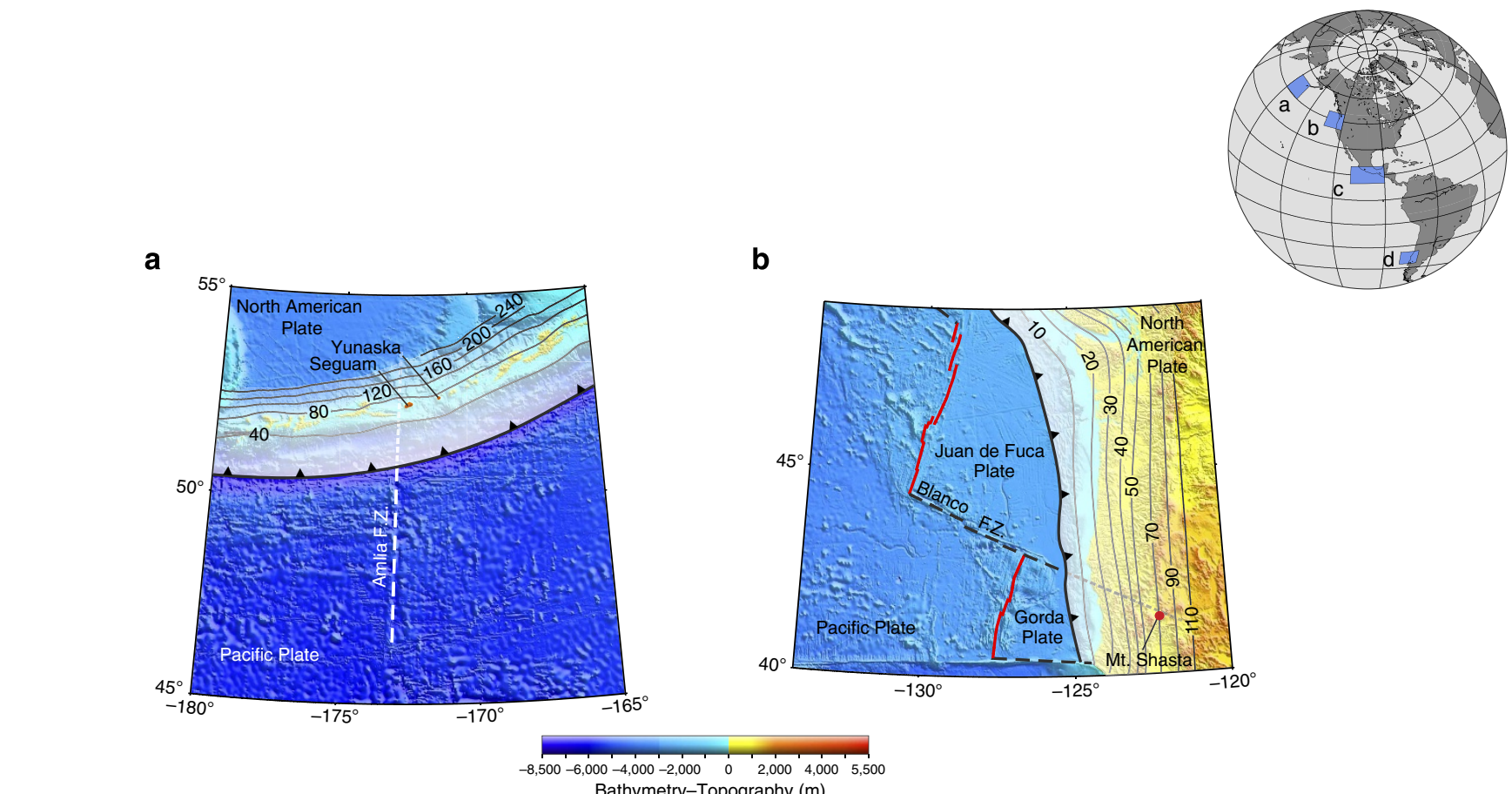

c

Colima

Bathymetry-Topography $(\mathrm{m})$
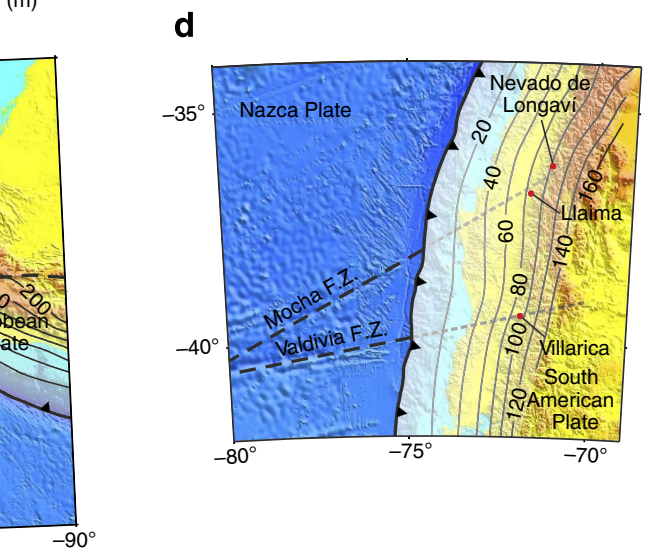

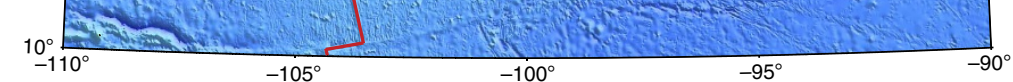

Figure 1 | Bathymetry and topography maps for four distinct subduction zones. Colour-coded maps (SRTM30_PLUS dataset ${ }^{65}$ ) for the (a) Aleutian, (b) Cascadia, (c) Mexican and (d) southern South America subduction zones. The location of fracture major zones is indicated with dashed lines, and volcanic centres characterized by highly hydrated magmas are displayed as red spots. Black isodepths lines show the position of the subducting slabs ${ }^{66,67}$ $\mathrm{FZ}$, fracture zone.

B-enrichment (that is, in $\mathrm{B} / \mathrm{Zr}$ ) in a restricted arc segment may either signify differences in source modification, or be attributed to local influences in magmatic processes as will be discussed below. The data considered in this paper are drawn from our own investigations and from published works where available $(c f$. Supplementary Note 2 for data sources; $c f$. Supplementary Note 3, Supplementary Tables 2-7 and Supplementary Fig. 2 on analytical details, precision and accuracy for new data). The compiled results are shown in Fig. 2 for the southern Andes and the Aleutians, both of which are associated with relatively cool subduction zones, and for the Cascades and the Trans-Mexican volcanic arcs, both of which correspond to young subduction zones with local extensional tectonics. B/Zr ratios are plotted versus along-arc position in latitudinal or longitudinal coordinates, bulk $\mathrm{SiO}_{2}$ contents and $\mathrm{Ba} / \mathrm{Zr}$ ratios. It should be noted that most samples are situated near the main volcanic front, albeit the Cascades and Andean data locally include samples ranging from frontal- to back-arc sites. For each arc, effort was made to include primitive mafic lavas but intermediate and evolved compositions are also included to provide better spatial coverage. Most samples are of Quaternary age $(<1 \mathrm{Ma})$. Note that data are also compiled for northern sectors of the Andes, but not discussed in any detail here. Northern Volcanic Zone volcanoes (mostly Ecuador) occur in a region of aseismic ridge subduction that adds considerable complexity to geodynamic considerations. Central Volcanic Zone (CVZ) samples are dominantly silicic (andesite to rhyolite) and too old ( $c a .4 \mathrm{Ma}$ or older age) to reflect modern subduction tectonics; moreover, many of the analyzed samples in this region exhibit evidence of strong crustal influence and are of dubious value in assessing arc mantle processes. In any case, $\mathrm{B} / \mathrm{Zr}$ values observed in Quaternary age Northern Volcanic Zone and CVZ samples are comparable to those seen in Southern Volcanic Zone (SVZ) samples.

$\mathrm{B} / \mathrm{Zr}$ ratios vary considerably in each of the arcs investigated, but usually exceed typical values $(\sim 0.01)$ for intraplate basalts with exception of some basalts from the Cascades and Mexican arcs. Maximum (and higher median) B/Zr values are seen in lavas from the relatively cool Aleutian and Andean arcs, and lower B/ $\mathrm{Zr}$ values (some approaching intraplate values) are observed in the warm Cascades and Mexican arcs. This pattern is consistent 

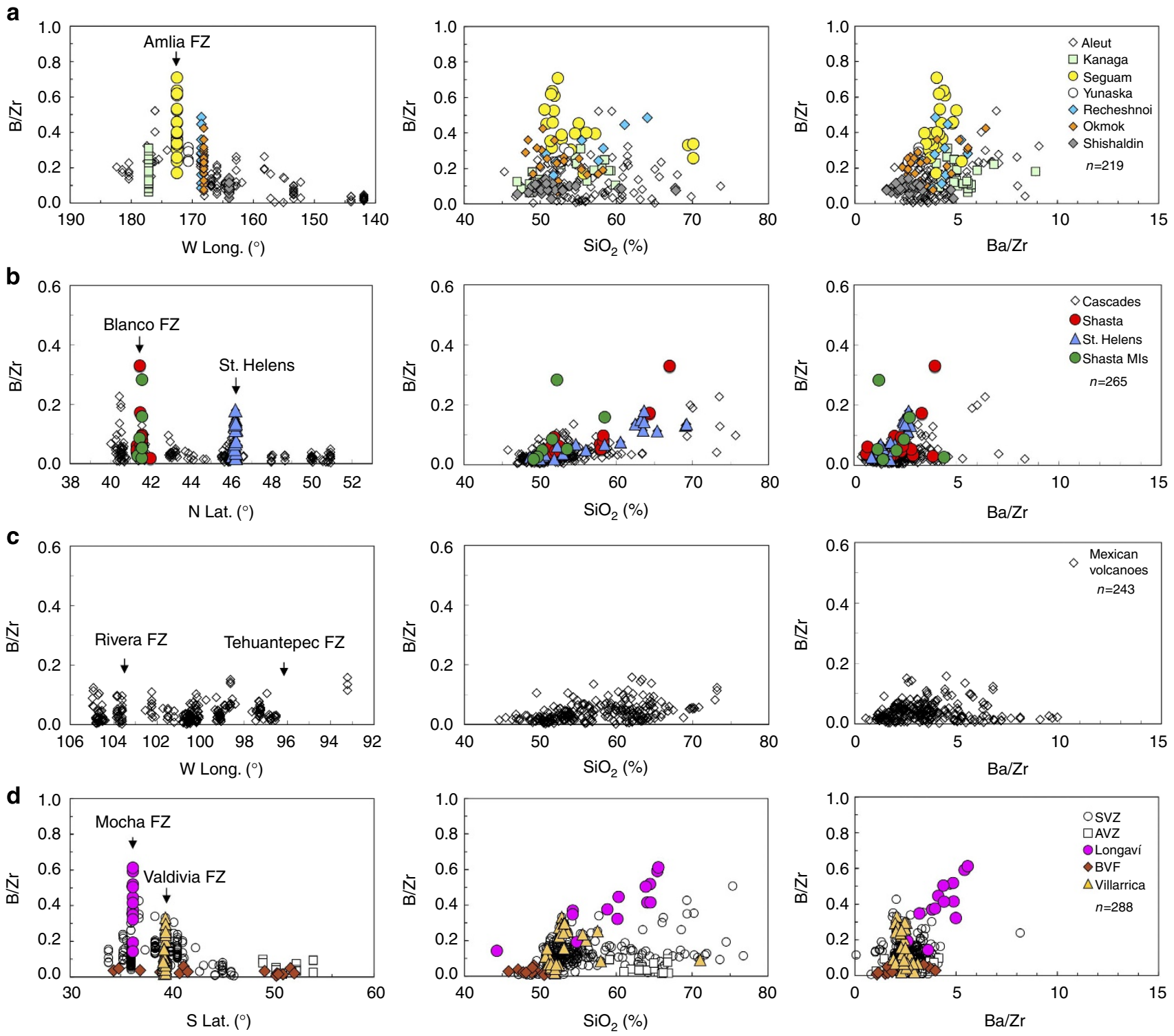

Figure 2 | Fluid-mobile element geochemistry of selected volcanic arcs. Fluid-mobile element geochemistry shows variation in whole-rock B/Zr as functions of along-strike position and proximity to major fracture zones ( $F Z$ ), silica content and covariation with $\mathrm{Ba} / \mathrm{Zr}$ ratios for (a) Aleutians,

(b) Cascades, (c) Mexico and (d) Andes volcanic arcs. Most B data were obtained by Prompt Gamma Neutron Activation (see refs 24,49) or ICP Emission Spectroscopy (see ref. 32) and uncertainties on plotted ratios generally are comparable to symbol size (see Supplementary Note 3 for full analytical details). The number $(n)$ of $B / Z r$ values is shown for each arc; counts for other parameters are given in Supplementary Dataset 1. AVZ, Austral Volcanic Zone (48-55'S); SVZ, Southern Volcanic Zone (33-46º S); BVF, behind volcanic front; Mls, melt inclusions.

with more dramatic loss of B and fluids from warmer slabs, and with progressive depletions across arcs as individual slabs become warmer with greater depth ( $c f$. ref. 40 ). Most notably, along-arc profiles for the Aleutians and southern Andes exhibit conspicuous spikes in $\mathrm{B} / \mathrm{Zr}$, where major fracture zones project beneath the arcs (data highlighted in yellow and magenta in Fig. 2). The definition of such spikes is somewhat arbitrary, but in the Aleutians B/Zr ratios in Seguam basalts (0.3-0.7) exceed those of nearly all other basaltic lavas in the arc as previously noted ${ }^{23,24}$. At Longaví mafic lavas are scarce, but mafic enclaves have higher $\mathrm{B} / \mathrm{Zr}$ values than seen in proximal SVZ basaltic lavas; additionally, andesitic and dacitic lavas have strikingly higher B/ $\mathrm{Zr}$ (all >0.3) than their SVZ counterparts, with the exception of basaltic andesites and andesites from Villarrica volcano. We note that these Andean anomalies are specific to Longaví and Villarrica and that samples from surrounding monogenetic mafic volcanoes have relatively low $\mathrm{B} / \mathrm{Zr}$ values $(<0.2)$ that seem to be representative of the SVZ in general. In contrast, the Cascades and Mexican volcanic arc profiles show only modest B-enrichment overall (B/Zr below 0.15 for most samples, and many below 0.05 ). In the Cascades, weak 'spikes' in B/Zr occur near Mt. Shasta and Mt. St. Helens, albeit basalts from these volcanoes have low $\mathrm{B} / \mathrm{Zr}$ values characteristic of much of the arc. There are no pronounced spikes evident in the Mexican arc. Data coverage is sparse near the projected locus of the Tehuantepec fracture zone (for example, near El Chichon). Whereas the projected subduction trajectory of the Rivera fracture zone passes beneath the well-sampled Colima Graben region. Subdued B-enrichment in this region could result from unique tectonic conditions (for example, presence of a slab gap beneath Colima ${ }^{41}$ ) as well as a higher temperature of the slab subducting under Mexico.

To better understand the significance of observed $\mathrm{B} / \mathrm{Zr}$ spikes, this ratio is also shown as a function of whole-rock $\mathrm{SiO}_{2}$ content (Fig. 2). Each highlighted case comprises a spectrum of basaltic to 
dacitic lavas. Notably, elevated but varied $\mathrm{B} / \mathrm{Zr}$ ratios in the mafic lavas suggest that their mantle sources have been enriched in $B$, albeit not uniformly so. At Seguam, all basaltic lavas have strongly elevated $\mathrm{B} / \mathrm{Zr}$ values (approximately $0.3-0.6$ ), and the range is likely inherited from variable fluid (and B) inputs to the mantle source of these lavas. More evolved Seguam lavas have B/Zr ratios overlapping the lower end of the range for basalts from this volcano, and consistent with their derivation by fractional crystallization of such parental magmas. At Longaví, elevated B/ $\mathrm{Zr}$ ratios (approximately $0.2-0.4$ ) in the most mafic lavas are consistent with source modification exceeding that elsewhere in the Andean $\mathrm{SVZ}^{32}$. Even higher $\mathrm{B} / \mathrm{Zr}$ ratios (up to $\sim 0.6$ ) in the evolved lavas may reflect involvement of more strongly modified sources, fractional crystallization from comparably B-enriched parental magmas (apparently unerupted) or an open-system process whereby B-enrichment is enhanced. Elsewhere in the SVZ, corresponding approximately to the projected locus of the Valdivia fracture zone, basalt to andesite lavas from the sector (lat. $39.4^{\circ}$ to $40.5^{\circ} \mathrm{S}$ ) between Villarrica and Puyehue stratovolcanoes also have relatively high $\mathrm{B} / \mathrm{Zr}(0.2-0.3)$. However, as previously noted, basaltic lavas from monogenetic vents near these volcanoes have lower $\mathrm{B} / \mathrm{Zr}(<0.1)$, and it appears that B-enrichment in the underlying mantle wedge must be heterogeneous and less extensive than at Longaví. We also note that very high $\mathrm{B} / \mathrm{Zr}$ values seen in some evolved lavas $\left(\mathrm{SiO}_{2}>\sim 70 \%\right)$ from the Andean $\mathrm{CVZ}$ are not correlated with fracture zone subduction, and likely reflect zircon fractionation or magma interaction with (or derivation from) B-rich lithologies (for example, sediments, evaporates) in the shallow Andean crust ${ }^{42,43}$.

Basaltic lavas near Mt. Shasta and Mt. St. Helens have B/Zr ratios (approximately 0.02-0.10) only slightly higher than observed in intraplate lavas, and essentially overlapping the range observed for mafic lavas elsewhere in the Cascades arc. Typically, Cascades $\mathrm{B} / \mathrm{Zr}$ values increase progressively with $\mathrm{SiO}_{2}$ content, and maximum values rarely exceed $\sim 0.2$ (the highest observed value is for a Shasta dacite; $\sim 0.3$ ). Thus, there is little evidence for pronounced B-enrichment anywhere in the Cascades. Published data for Cascades MIs indicate relatively low $\mathrm{H}_{2} \mathrm{O}$ contents (for arcs) typically on the order of $2 \%$ or less for basaltic magmas $^{26,44-46}$ and up to $2-4 \%$ in lavas of intermediate and more evolved composition ${ }^{45,47}$. As noted earlier, the relatively 'dry' character of Cascades volcanic rocks likely reflects strong devolatilization of the young and slowly subducting Cascadia slab, with significant fluid (and B) losses beneath the frontal arc region (cf. refs 48,49). MIs from Mt. Shasta area samples typically have low-B contents and $\mathrm{B} / \mathrm{Zr}$ ratios overlapping values for whole rock lavas (Fig. 2). However, two MIs from a hybrid high-Mg andesite lava (Whaleback shield volcano) do have elevated $\mathrm{B}$ and $\mathrm{B} / \mathrm{Zr}$ (nearly 0.3 in a basaltic andesite glass ${ }^{45}$ ), which could be attributed to at least occasional influx of B-rich fluids beneath that region.

Because $\mathrm{Ba}$ is commonly considered to be a fluid-mobile element, and a proxy for involvement of slab-derived fluids in arc magmas ( $c f$. ref. 50$), \mathrm{B} / \mathrm{Zr}$ and $\mathrm{Ba} / \mathrm{Zr}$ ratios are also compared in Fig. 2. Normalization to $\mathrm{Zr}$ emphasizes selective $\mathrm{B}$ or $\mathrm{Ba}$ fractionation because of processes other than melting or crystal fractionation, neither of which is likely to significantly modify these ratios, except possibly in strongly evolved magmas. Notable separation of Seguam and Longaví lavas from the bulk Aleutian and Andean fields, respectively, emphasizes unique modifications of their sources relative to other sectors of these arcs, and clearly $\mathrm{B}$ is the stronger discriminant of the two. In contrast, for the Cascades and Mexico arcs there is significant variation in $\mathrm{Ba} / \mathrm{Zr}$ with only modest variation in $\mathrm{B} / \mathrm{Zr}$, and little evidence for anomalous source modifications along strike. Thus, in relatively dry and hot subduction zones, Ba-enrichment may dominantly reflect input of a sediment melt component, rather than a fluid, as proposed by some authors ${ }^{51}$.

Numerical modelling. To better understand how subduction of mechanically weak fracture zone rocks may account for unusual arc volcanism (Fig. 1), we use high-resolution three-dimensional coupled petrological-thermomechanical simulations of fracture zone subduction to predict the spatial evolution of melt and hydrous fluid content above subducting slabs in these settings. As detailed in the Methods section, we performed numerical experiments to evaluate the effect of laterally heterogeneous subducting plates by introducing a mechanically weak fracture zone corresponding to a predefined set of plate age offsets and rheological parameters (see Supplementary Fig. 3). The rheology of fracture zones is not well known, although it is commonly accepted that they are serpentinized and mechanically weak ${ }^{9}$. Our approach towards evaluating the effect of fracture zone subduction involves a set of numerical models covering initial conditions that range from a simple subduction model with an oceanic plate age offset only, to more complex models incorporating the presence of a weak and partially serpentinized layer corresponding to the location of a fracture zone. Figure $3 \mathrm{a}$ shows the result of a subduction experiment after $17.5 \mathrm{Myr}$ of convergence where the oceanic plate includes an age offset of $10 \mathrm{Ma}$, but without a preexisting lithospheric weakness located across the age offset. During subduction, the progressive hydration of the mantle wedge by slab dehydration induces partial melting above the subducting plate at a depth of $\sim 125 \mathrm{~km}$. The melting front accumulates rather uniformly along strike with no significant variations caused by the presence of the $10 \mathrm{Ma}$ age offset in the oceanic lithosphere (Fig. 3a). Also the slab temperature is not affected other than the normal temperature distribution specific for the presence of a $10 \mathrm{Ma}$ age offset (Fig. 4a). Similarly uniform melt distributions in the mantle wedge (and slab temperature profiles vs depth) are observed when we increased the lithospheric age shift in the incoming oceanic plate from 5 to $20 \mathrm{Ma}$ (Supplementary Fig. 4) or varied the incoming slab age from 10 to $50 \mathrm{Ma}$ (Supplementary Fig. 5). To evaluate further the impact of fracture zone subduction on arc magma sources along arcs, we added the presence of a mechanically weak zone. For this set of simulations, we impose a narrow (10 km wide) weak zone extending vertically downward from the base of the oceanic crust to a depth of several kilometers into the upper part of the lithosphere. To cover a realistic range of parameters specific for serpentinite rocks associated with fracture zones, we varied the maximum depth $(5-10-20 \mathrm{~km})$ and density $\left(2,800-3,000-3,200 \mathrm{~kg} \mathrm{~m}^{-3}\right)$ of the serpentinized layer (Fig. 2b,d). Figures $3 \mathrm{~b}$ and $4 \mathrm{~b}$ display the result of a subduction experiment after 17.5 Myr of convergence where we include a 10$\mathrm{km}$ wide by a $10-\mathrm{km}$ deep mechanically weak zone, with a rheology specific for serpentinite. In contrast with previous experiments, this model shows several striking features regarding melt distribution in the mantle wedge and slab temperature. The presence of a weak fracture zone in the subducting slab perturbs the uniform distribution of melt in the mantle wedge and triggers the development of an upwelling plume of partially molten and hydrated mantle rocks, locally enhancing the melt productivity in the wedge (Figs $3 \mathrm{~b}$ and $4 \mathrm{~b}$ ). The formation of the upwelling plume starts $\sim 12 \mathrm{Myr}$ after subduction initiation, and then attains its full growth at $\sim 17.5 \mathrm{Myr}$ (see Supplementary Fig. 6). The subducting slab temperature distribution is also strongly affected, whereby the weak fracture zone locally increases the temperature at the top of the slab by almost $100^{\circ} \mathrm{C}$ (Fig. $4 \mathrm{~b}$ ). A closer examination of the subduction process reveals 
that the weakened serpentinized fracture zone is partially scraped out in the forearc region because of its low strength and positive buoyancy. This in turn creates a trench-orthogonal linear depression on the surface of the slab that subsequently is in-filled by hot surrounding mantle material (Fig. 5). Resulting high temperatures accelerate dehydration of the subducting slab and serpentinite and release of $\mathrm{H}_{2} \mathrm{O}$-rich fluids above the fracture zone, causing extensive hydration of the overlying ultramafic mantle wedge. In such regions, plume-like instabilities may be triggered by excessive fluxing of hydrous fluids (0.2-0.7-wt\% of slab-derived water) released into the mantle wedge by the serpentinized fracture zone, and driven upward at shallower levels by compositional variations, density contrast and viscous heating ${ }^{52}$. We postulate that fluid-mobile trace elements such as B are released in excess as well, owing to their concentration in and release from the serpentinized materials. Because less fluid-mobile elements (for example, $\mathrm{Zr}$, $\mathrm{Nb}$ ) are less likely to be released in an equally efficient manner, the slab-derived fluids could impose a 'B-spike' on infiltrated regions of the mantle wedge while simultaneously facilitating the onset of melting to produce arc magmas. For example, if subduction zone fluids can carry 100's of p.p.m. B (and essentially no $\mathrm{Zr}, \mathrm{Nb}, \mathrm{La}$ ), the amount of fluid required to change $\mathrm{B} / \mathrm{Zr}$ in primitive mantle (for example, OIB source) to typical modified arc mantle may be only a few tenths of a percent by weight; and to reach higher $\mathrm{B} / \mathrm{Zr}$ associated with fracture zone subduction, only slightly higher proportions of fluid are required (cf. ref. 53). a

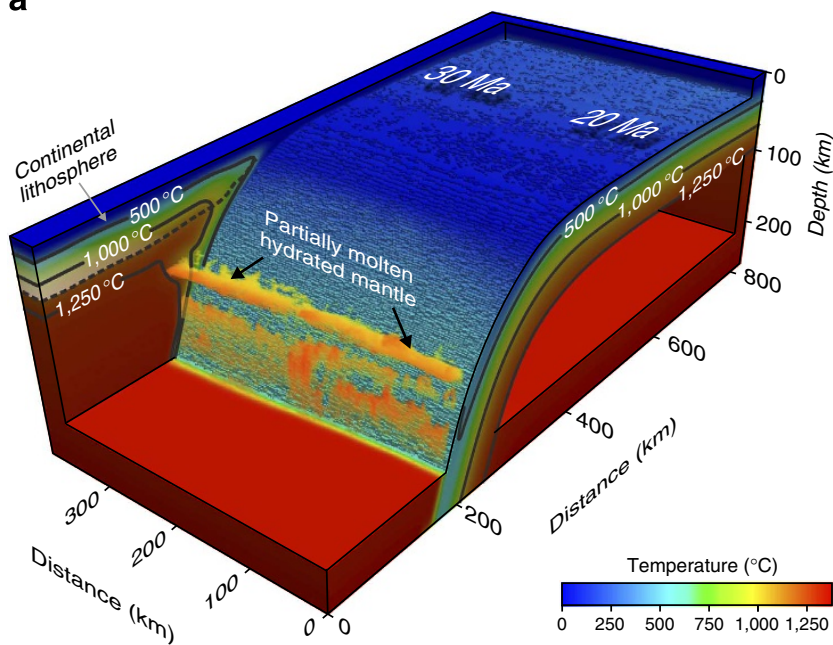

b

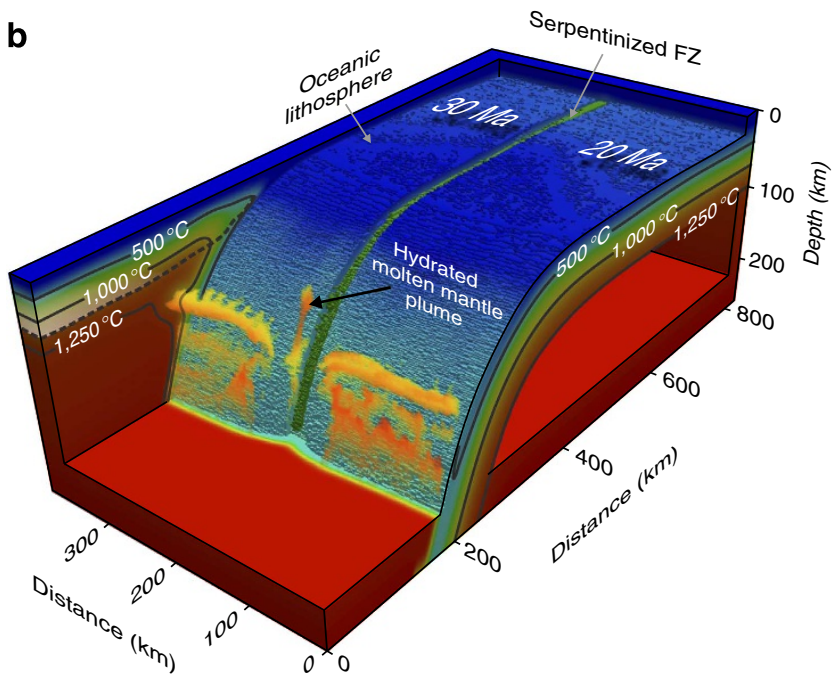

Figure 3 | Temperature and composition after 17.5 Myr of convergence. (a) Numerical experiment with a heterogeneous subducting plate (20-30 Ma). (b) Numerical experiment with a heterogeneous subducting plate (20-30 Ma) and partially serpentinized fracture zone $\left(h_{\text {serp. f.z. }}=10 \mathrm{~km}\right.$; $\rho_{\text {serp. f.z. }}=2,800 \mathrm{~kg} \mathrm{~m}^{-3}$ ). Green strip in the middle of the oceanic plate represents the serpentinized fracture zone, and partially molten mantle above the slab is coloured according to the temperature. Dashed line represents the base of the continental lithosphere.

a

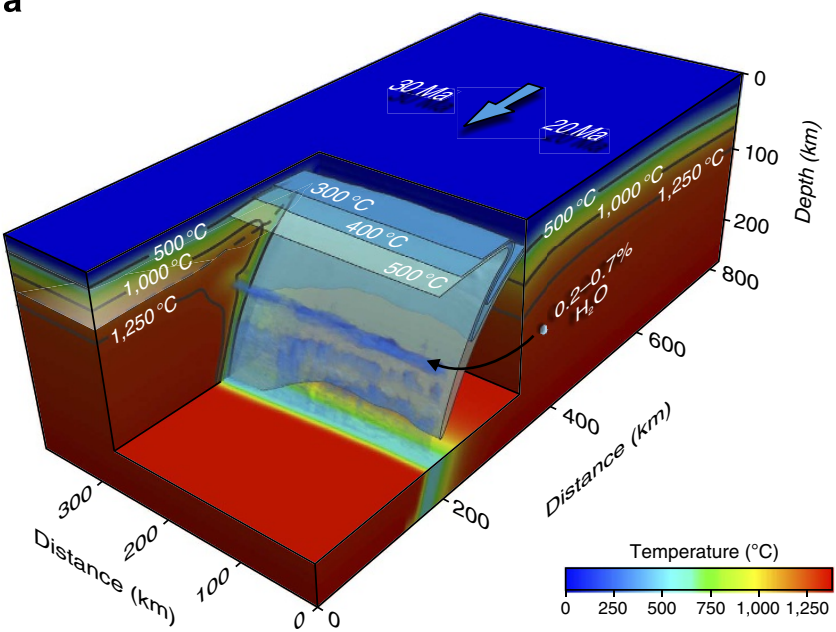

b

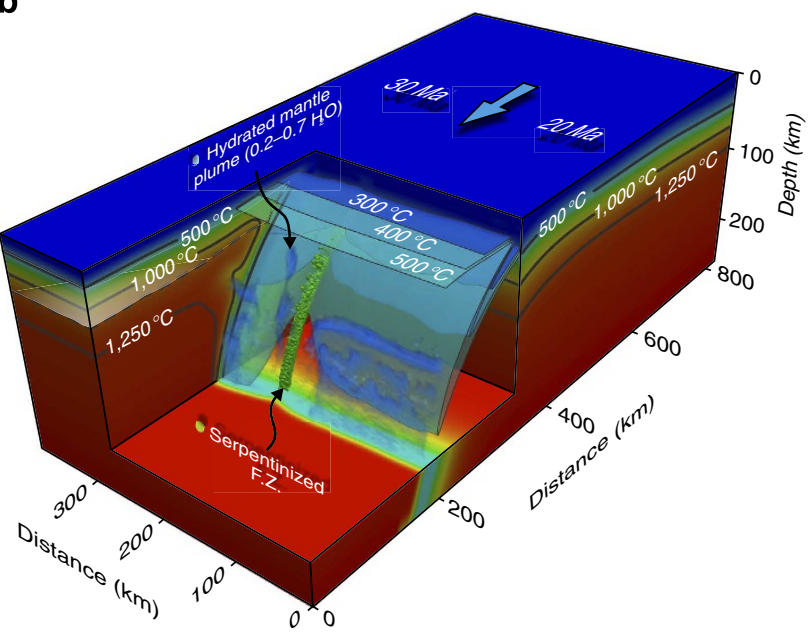

Figure 4 | Slab temperature and $\mathbf{H}_{\mathbf{2}} \mathbf{O}$ distribution after 17.5 Myr of convergence. (a) Numerical experiment with a heterogeneous subducting plate (20-30 Ma). (b) Numerical experiment with a heterogeneous subducting plate (20-30 Ma) and partially serpentinized fracture zone $\left(h_{\text {serp. f.z. }}=10 \mathrm{~km}\right.$; $\rho_{\text {serp. f.z. }}=2,800 \mathrm{~kg} \mathrm{~m}^{-3}$ ). Slab temperature is shown as semitransparent (blue tones) isosurfaces and hydrated mantle and plume above the slab is coloured in light blue. 

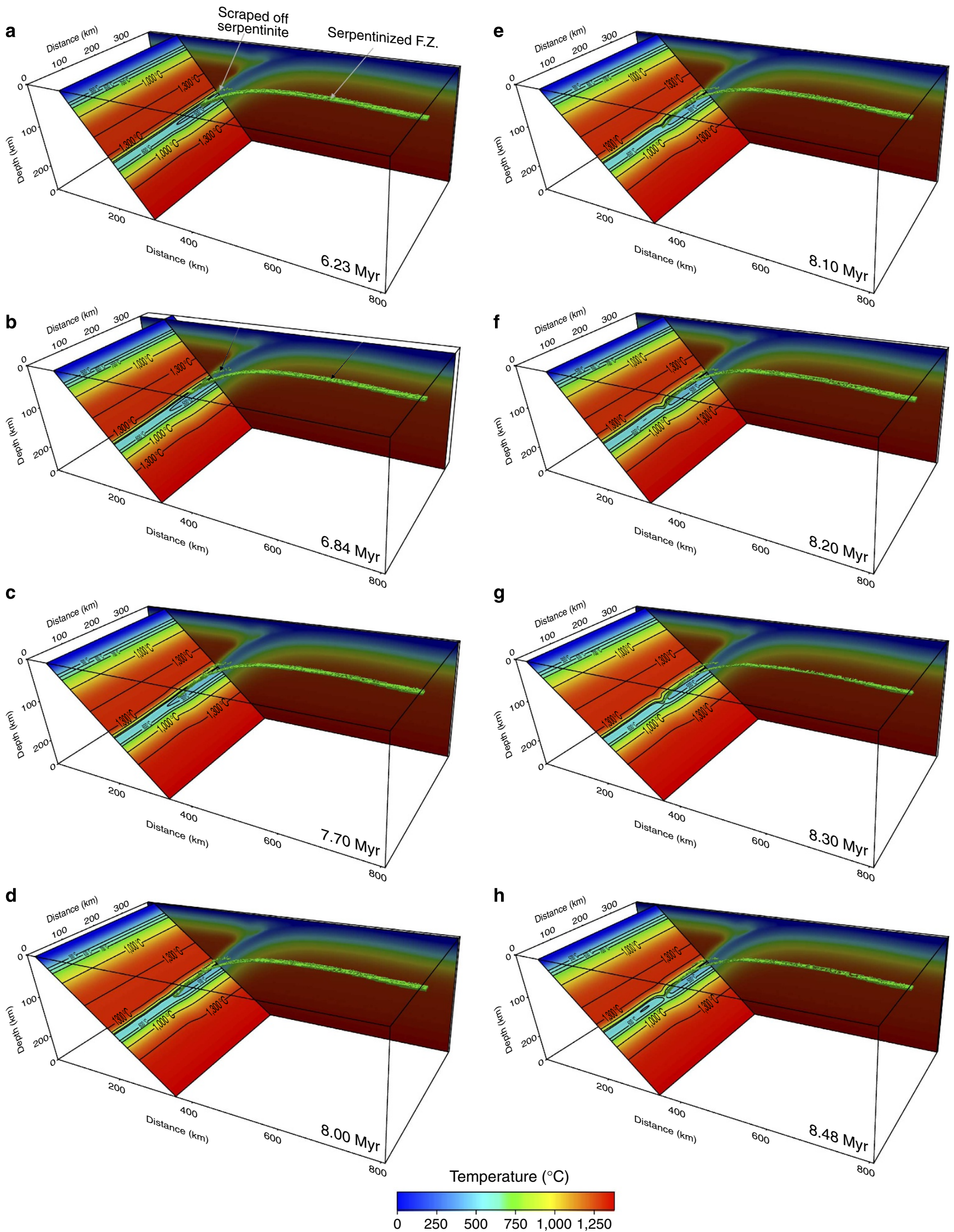

Figure 5 | Slab temperature evolution for a subduction experiment with serpentinized fracture zone. (a-h) The evolution from 6.23 to 8.48 Myr. The partially serpentinized fracture zone has the following characteristics: $h_{\text {serp. f.z. }}=10 \mathrm{~km}$ and $\rho_{\text {serp. f.z. }}=2,800 \mathrm{~kg} \mathrm{~m}^{-3}$. The slice through this model is normal to the slab surface and illustrates that at B8.10 Myr the slab temperature starts to increase in the region of fracture zone subduction (e). 


\section{Discussion}

There is strong evidence for anomalous enrichment of B and other fluid-mobile elements in arc magma sources associated with subduction of fracture zones (Figs 1 and 2). This is best explained in terms of infiltration of anomalous volumes of B-rich fluids, unusually high B contents in such fluids, or both. To a large degree, this is likely to be a near instantaneous phenomenon (that is, associated with Quaternary subduction rather than a timeintegrated effect) because in most cases the locus of fracture zones-arc convergence migrates along the arc with time. The Andes SVZ may be a good place to explore such 'migratory effects', because $\mathrm{B}$ data there show a broad B/Zr anomaly that may result from such an effect. Although the present data set is too limited to rigorously evaluate spatial-temporal variations in slab fluid proxies, this would be an interesting research topic to pursue in the future.

The magnitude of fluid flux to the mantle wedge can only be estimated in a relative sense without more detailed knowledge of actual slab geochemical inventories and consideration of thermal evolution, both of which vary from arc to arc. As previously noted, initial inventories of fluids and fluid-mobile elements in subducting slabs are controlled by geologic factors (for example, degree of alteration of ocean crust, type and thickness of overlying sediments). The presence of fracture zones will likely enhance the initial inventories, but to varying extent judging from differences in B-enrichment associated with the Mocha and Valdivia fracture zones. Retention of these inventories to sub-arc depths hinges on the thermal maturity and metamorphic history of the slab, and is most efficient for cooler slabs. Compared with other arcs, the overall limited B-enrichments in Cascades and Mexican arc lavas can be attributed largely to the advanced thermal maturity of their respective slabs, with significant decimation of initial $\mathrm{B}$ inventories before reaching sub-arc depths. In addition, local extension in the Cascades and Mexican arcs may be associated with decompression melting of upwelling asthenospheric mantle that has been little-modified by slab-derived fluids, and produces 'intra-plate-like' mafic magmas (cf. refs 54-56). Tectonic imperfections in the subducting slab, such as a postulated slab gap beneath the Colima region in western Mexico ${ }^{41}$, could also allow upwelling of asthenospheric mantle. In some instances, large variations in $\mathrm{B} / \mathrm{Zr}$ (and similar ratios) are observed at individual arc volcanoes or local regions. Among many possibilities, a likely explanation is that the mantle wedge is heterogeneously modified by slab inputs. In cool subduction zones, high fluid flux may overwhelmingly modify the mantle wedge; conversely, in warm subduction zones with low fluid flux, the mantle wedge may be modified only slightly (or locally). In the latter case (for example, Cascades or Mexico), a greater diversity of magma types is seen, some of which may be derived from hardly modified asthenospheric mantle. Finally, as illustrated in Supplementary Note 1, trace element proxies for fluxes of slab-derived fluids in subduction zones are imperfect, as are direct estimates of magmatic fluid contents. The proxies are best used to assess relative differences in slab fluid fluxes within individual volcanic arcs where physical subduction parameters (plate age, subduction rate) are comparable along strike.

Critical to our understanding of arc magma genesis and its along-arc variability is the melting zone distribution in the mantle wedge above the subducted fracture zone. To illustrate how fracture zones influence melt patterns above slabs, we employed three-dimensional high-resolution coupled petrological-thermomechanical numerical models of subduction. Modelling results show that pure thermal gradients across fracture zones in the oceanic slabs are not able to explain the observed anomalous enrichment in fluid-mobile elements in arc magma sources associated with subduction of fracture zones (Fig. 3a). However, introducing a zone of weakness corresponding to the position of fracture zone, our modelling suggests that regional variations of both slab temperature and mantle wedge melt distribution are guided by the position of the subducted fracture zone (Figs $3 \mathrm{~b}$ and $4 \mathrm{~b}$ ). The combination of low strength and positive buoyancy (partial serpentinization) associated with a fracture zone produces a trench-orthogonal linear depression on the surface of the slab that is in-filled by hot surrounding mantle material (Supplementary Fig. 6). The increased slab temperature in this region causes a stronger dehydration of the incoming plate along the fracture zone, triggering a partially molten and hydrated thermal-chemical instability (Supplementary Fig. 6). Considering a wide range of parameters related with the fracture zone (densities of $2,800-3,200 \mathrm{~kg} \mathrm{~m}^{-3}$, and thicknesses of $5-20 \mathrm{~km}$ ), our modelling predicts consistent outcomes: that is, the numerical results show the same pattern for mantle wedge melt/fluid distribution along the strike and the development of partially molten hydrous instabilities above the subducted serpentinized fracture zone (Supplementary Fig. 7).

Our modelling results are in good agreement with recent studies in the Villarrica region of the Andean SVZ that revealed the existence of physical anomalies related to the subduction of the Valdivia fracture zone (Fig. 1). Specifically, the projected trace of this fracture zone, between $39^{\circ} \mathrm{S}$ and $40^{\circ} \mathrm{S}$ in the forearc region, corresponds to a negative gravity anomaly of $-50 \mathrm{mGal}$ (refs $57,58)$, a local minimum in plate coupling and aseismic slip ${ }^{59}$, and reduced seismic velocities coupled with an increased $V_{\mathrm{p}} / V_{\mathrm{s}}$ ratio $^{33}$, all of which suggest the localized existence low-strength/ low-density material and enhanced fluid release.

In this study, combined geochemical observations and robust numeric modelling results confirm that the subduction of weak serpentinized fracture zones is a first-order geodynamic process that contributes to significant variations in the composition and fluid content of magmas along volcanic arcs.

\section{Methods}

Model parameters and boundary conditions. The modelling was performed using the finite difference code I3ELVIS with marker-in-cell technique and multigrid approach ${ }^{60}$. The three-dimensional numerical model simulates selfsustaining subduction of an oceanic plate beneath a continental plate, where only internal forces drive the model evolution. The computations are performed within a Cartesian domain $808 \mathrm{~km}$ long, $392 \mathrm{~km}$ wide and $264 \mathrm{~km}$ deep (Supplementary Fig. 3). This domain is evenly divided into $404 \times 196 \times 132$ Eulerian grid cells (corresponding to a $2 \times 2 \times 2 \mathrm{~km}$ staggered grid resolution), which contain 180 million randomly distributed Lagrangian markers. The mechanical boundary conditions are as follows: the top boundary is free slip and the bottom boundary is permeable in the vertical direction; lateral boundaries are free slip except the latera boundary corresponding to the oceanic plate, which has prescribed a constant subduction velocity of $6.5 \mathrm{~cm}$ per year, and the lateral boundary corresponding to the oceanic plate, which has a non-slip condition. The subducted oceanic crust includes an upper layer of sediments ( $2 \mathrm{~km}$ thick) overlying a $2-\mathrm{km}$ thick layer of basalt and a $5-\mathrm{km}$ thick layer of gabbroic rocks. The continental crust comprises an upper layer ( $23 \mathrm{~km}$ thick) and a lower layer ( $12 \mathrm{~km}$ thick) of felsic rocks. The mantle consists of anhydrous peridotite (see material properties in Supplementary Table 1). The initiation of subduction is set by introducing an initial rheological weak zone with wet olivine rheology and low brittle/plastic strength

(Supplementary Fig. 3b). The top surface of the model is treated as an internal free surface by using a $12-\mathrm{km}$ thick top layer with low viscosity and low density $\left(10^{18} \mathrm{Pas}\right.$ and $\left.1 \mathrm{~kg} \mathrm{~m}^{-3}\right)$, overlying a $3-\mathrm{km}$ thick water layer $\left(10^{18} \mathrm{~Pa} \mathrm{~s}\right.$ and $\left.1,000 \mathrm{~kg} \mathrm{~m}^{-3}\right)$. This weak layer is used to minimize shear stresses $\left(<10^{4} \mathrm{~Pa}\right)$ and reproduce free surface at the top of the lithosphere ${ }^{61}$. The initial thermal structure is described by a thermal boundary layer (age controlled) at the top (see Supplementary Fig. 3a).

The initial fracture zone geometry corresponds to the location of the ocean plate age offset. In our models, water is present in sediments, hydrothermally altered basalt and serpentinized fracture zone.

Slab dehydration and mantle hydration reactions are assigned for P-T conditions computed from the thermodynamic database. Proportion of serpentine in hydrated mantle is limited by the $2 \mathrm{wt} \%$ cutoff limit of water content because of assumed incomplete (large-scale) serpentinization, which is in agreement with seismic constraints ${ }^{17,62}$. In addition, latent heat of partial melting and crystallization is taken into account. We use fluid markers to show the release and 
propagation of fluids into the overlying mantle wedge. Dehydration reactions lead to the release of a certain amount of fluid that is stored in a water marker. We imposed an upward vertical speed for free water of $10 \mathrm{~cm}$ per year. When this water marker encounters a rock capable of absorbing water, either by hydration or melting reactions, the fluid marker is consumed ${ }^{63}$. Rock markers are used to compute equilibrium water content at each numerical time step with the help of P-T- $\mathrm{H}_{2} \mathrm{O}$ tables computed with PERPLE_X ${ }^{63}$. We also included markers in the modelling of melting processes where both, hydrous and dry melting, are a nonlinear function of pressure and temperature ${ }^{64}$. Markers track the amount of melt extracted, and the total amount of melt for every marker takes into account the amount of previously extracted melt.

We use a constant viscosity of $10^{19} \mathrm{~Pa}$ for partially molten rocks in all our numerical experiments, and the lower and upper cutoff range for viscosity of all types of rocks is $10^{19}-10^{24} \mathrm{~Pa}$ s. Other parameters used in the numerical model are shown in Supplementary Table 1.

\section{References}

1. Menard, H. W. \& Atwater, T. Origin of fracture zone topography. Nature 222, 1037-1040 (1969).

2. Wessel, P. \& Haxby, W. F. Thermal stresses, differential subsidence, and flexure at oceanic fracture zones. J. Geophys. Res. 95, 375-391 (1990).

3. Haxby, W. F. \& Parmentier, E. M. Thermal contraction and the state of stress in the oceanic lithosphere. J. Geophys. Res. 93, 6419-6429 (1988).

4. Bonatti, E. Vertical tectonism in oceanic fracture zones. Earth Planet. Sci. Lett. 37, 369-379 (1978).

5. Lowrie, A., Smoot, C. \& Batiza, R. Are oceanic fracture zones locked and strong or weak?: New evidence for volcanic activity and weakness. Geology 14, 242-245 (1986).

6. Hall, C. \& Gurnis, M. Strength of fracture zones from their bathymetric and gravitational evolution. J. Geophys. Res. 110, B01402 (2005).

7. Bergman, E. A. \& Solomon, S. C. On the strength of oceanic fracture zones and their influence on the intraplate stress field. J. Geophys. Res. 97, 339-15,350 (1992).

8. Escartin, J., Hirth, G. \& Evans, B. Strength of slightly serpentinized peridotites: implications for the tectonics of oceanic lithosphere. Eology 29, 1023-1026 (2001).

9. Hilairet, N. et al. High-pressure creep of serpentine, interseismic deformation, and initiation of subduction. Science 318, 1910-1913 (2007).

10. Wenner, D. B. \& Taylor, H. P. Oxygen and hydrogen isotope studies of the serpentinization of ultramafic rocks in oceanic environments and continental ophiolite complexes. Am. J. Sci. 273, 207-239 (1973).

11. Selles, D., Rodriguez, C., Duncan, M., Naranjo, J. \& Gardeweg, M. Geochemistry of the Nevado de Longaví volcano $\left(36.2^{\circ} \mathrm{S}\right)$ : a compositionally atypical volcano in the Southern Volcanic Zone of the Andes. Revista Geologica de Chile 31, 293-315 (2004).

12. Jicha, B. R. et al. Variable impact of the subducted slab on Aleutian island arc magma sources: evidence from $\mathrm{Sr}, \mathrm{Nd}, \mathrm{Pb}$, and $\mathrm{Hf}$ isotope sand trace element abundances. J. Petrol. 45, 1845-1875 (2004).

13. Contreras Reyes, E. Evolution of the Seismic Structure of the Incoming/ Subducting Oceanic Nazca Plate off South Central Chile $152(\mathrm{PhD}$ thesis, Christian-Albrechts-Universitat zu Kiel, 2008).

14. Manea, M. \& Manea, V. C. On the origin of El Chichon volcano and subduction of Tehuantepec Ridge: A geodynamical perspective. J. Volcanol. Geotherm. Res. 175, 459-471 (2008).

15. Johnston, M. D., Long, M. D. \& Silver, P. G. State of stress and age offset at oceanic fracture zones and implications for the initiation of subduction. Tectonophysics 512, 47-59 (2011)

16. Peacock, S. M. Fluid processes in subduction zones. Science 248, 329-337 (1990).

17. Bostock, M. G., Hyndman, R. D., Rondenay, S. \& Peacock, S. M. An inverted continental Moho and serpentinization of the forearc mantle. Nature 417, 536-538 (2002).

18. Kerrick, D. Serpentinite seduction. Science 298, 1344-1345 (2002).

19. Ulmer, P. \& Trommsddorff, V. Serpentine stability to mantle depths and subduction-related magmatism. Science 256, 858-861 (1995).

20. Gill, J. B. Orogenic Andesites and Plate Tectonics 336 (Springer, 1981).

21. Tatsumi, Y. \& Eggins, S. Subduction Zone Magmatism (Blackwell Science,, 1995).

22. Elliott, T., Plank, T., Zindler, A., White, W. \& Bourdon, B. Element transport from slab to volcanic front at the Mariana Arc. J. Geophys. Res. 102, 14991-15019 (1997)

23. Singer, B. S., Leeman, W. P., Thirlwall, M. F. \& Rogers, N. W. in Subduction Top to Bottom. Geophys. Monogr. Ser. Vol. 96 (eds Bebout, G. E. et al.) 285-291 (AGU, Washington, DC, 1996).

24. Singer, B. S. et al. Along strike trace element and isotopic variation in Central Aleutian Island arc basalt: Subducted sediments melt and serpentine dehydrates. J. Geophys. Res. 112, B06206 (2007).

25. Singer, B. S., Myers, J. D. \& Frost, C. D. Mid-Pleistocene basalts from the Seguam volcanic center, central Aleutian arc, Alaska: local lithospheric structures and source variability in the Aleutian arc. J. Geophys. Res. 97, 4579-4586 (1992).

26. Ruscitto, D. M., Wallace, P. J. \& Kent, A. J. R. Revisiting the compositions and volatile contents of olivine-hosted melt inclusions from the Mount Shasta region: Implications for the formation of high-Mg andesites. Contrib. Mineral. Petrol. 162, 109-132 (2011).

27. Martin, E., Bindeman, I. \& Grove, T. L. The origin of high-Mg magmas in Mt. Shasta and Medicine Lake volcanoes, Cascade Arc (California): higher and lower than mantle oxygen isotope signatures attributed to current and past subduction. Contrib. Mineral. Petrol. 162, 945-960 (2011).

28. Grove, T. L., Parman, S. W., Bowring, S. A., Price, R. C. \& Baker, M. B. The role of an $\mathrm{H}_{2} \mathrm{O}$-rich fluid component in the generation of primitive basaltic andesites and andesites from the Mt. Shasta region, N. California. Contrib. Mineral. Petrol. 142, 375-396 (2002).

29. Scambelluri, M., Fiebig, J., Malaspina, N., Muentener, O. \& Pettke, T. Serpentinite subduction: Implications for fluid processes and trace-element recycling. Int. Geol. Rev. 46, 595-613 (2004).

30. Kodolányi, J. \& Pettke, T. Loss of trace elements from serpentinites during fluid-assisted transformation of chrysotile to antigorite-an example from Guatemala. Chem. Geol. 284, 351-362 (2011).

31. Luhr, J. F., Carmichael, I. S. E. \& Varekamp, J. C. The 1982 eruptions of El Chichon volcano, Chiapas, Mexico: mineralogy and petrology of anhydritebearing pumices. J. Volcanol. Geotherm. Res. 23, 29-108 (1984).

32. Rodriguez, C., Selles, D., Dungan, M. A., Langmuir, C. H. \& Leeman, W. P. Adakitic dacites formed by intracrustal crystal fractionation of water-rich parent magmas at Nevado de Longaví volcano $\left(36.2^{\circ} \mathrm{S}\right.$; Andean Southern Volcanic Zone, central Chile). J. Petrol. 48, 2033-2061 (2007).

33. Dzierma, Y. et al. Seismic velocity structure of the slab and continental plate in the region of the 1960 Valdivia (Chile) slip maximum-insights into fluid release and plate coupling. Earth Planet. Sci. Lett. 331-332, 164-176 (2012).

34. Leeman, W. P. \& Sisson, V. B. in Boron: Mineralogy, Petrology, and Geochemistry. Reviews in Mineralogy, v. 33 (eds Grew, E. S. \& Anovitz, L. M.) 645-707 (Mineralogical Society of America, 1996).

35. Ryan, J. G., Leeman, W. P., Morris, J. D. \& Langmuir, C. H. The boron systematics of intraplate lavas: Implications for crust and mantle evolution. Geochim. Cosmochim. Acta 60, 415-422 (1996).

36. Bebout, G. E., Ryan, J. G., Leeman, W. P. \& Bebout, A. E. Fractionation of trace elements by subduction-zone metamorphism - Effect of convergent margin thermal evolution. Earth Planet. Sci. Lett. 171, 63-81 (1999).

37. Brenan, J. M., Ryerson, F. J. \& Shaw, H. R. The role of aqueous fluids in the slab-to-mantle transfer of boron, beryllium, and lithium during subduction: Experiments and model. Geochim. Cosmochim. Acta 62, 3337-3347 (1998).

38. Marschall, H. R., Altherr, R. \& Rupke, L. Squeezing out the slab-modeling the release of $\mathrm{Li}, \mathrm{Be}$, and $\mathrm{B}$ during progressive high-pressure metamorphism. Chem. Geol. 239, 323-335 (2007).

39. Morris, J. D., Leeman, W. P. \& Tera, F. Be isotope and B/Be constraints on a subduction contribution to volcanic arc magmas. Nature 344, 31-36 (1990).

40. Ryan, J. G., Morris, J., Tera, F., Leeman, W. P. \& Tsvetkof, A. Cross-arc geochemical variations in the Kurile arc as a function of slab depth. Science 270, 625-628 (1995).

41. Yang, T. et al. Seismic structure beneath the Rivera subduction zone from finite-frequency seismic tomography. J. Geophys. Res. 114, B01302 (2009).

42. Kasemann, S., Erzinger, J. \& Franz, G. Boron recycling in the continental crust of the central Andes from the Paleozoic to Mesozoic, NW Argentina. Contrib. Mineral. Petrol. 140, 328-343 (2000).

43. Trumbull, R. B. et al. Evidence for late Miocene to recent contamination of arc andesites by crustal melts in the Chilean Andes $25-26^{\circ} \mathrm{S}$ and its geodynamic implications. J. South Am. Earth Sci. 12, 135-155 (1999).

44. Sisson, T. W. \& Layne, G. D. $\mathrm{H}_{2} \mathrm{O}$ in basalt and basaltic andesite glass inclusions from four subduction-related volcanoes. Earth Planet. Sci. Lett. 117, 619-635 (1993).

45. Ruscitto, D. M., Wallace, P. J., Johnson, E. R., Kent, A. J. R. \& Bindeman, I. N. Volatile contents of mafic magmas from cinder cones in the central Oregon High Cascades: ilmplications for magma formation and mantle conditions in a hot arc. Earth Planet. Sci. Lett. 298, 153-161 (2010).

46. Le Voyer, M., Rose-Koga, E. F., Shimizu, N., Grove, T. L. \& Sciano, P. Two contrasting $\mathrm{H}_{2} \mathrm{O}$-rich components in primary melt inclusions from Mount Shasta. J. Petrol. 51, 1571-1595 (2010).

47. Ruscitto, D., Wallace, P. J., Cooper, L. \& Plank, T. Global Variations in $\mathrm{H}_{2} \mathrm{O} / \mathrm{Ce}$ II: relationships to arc magma geochemistry and volatile fluxes. Geochem. Geophys. Geosyst. 13, Q03025 (2012).

48. Hyndman, R. D. \& Peacock, S. M. Serpentinization of the forearc mantle. Earth Planet. Sci. Lett. 212, 417-432 (2003).

49. Leeman, W. P., Tonarini, S., Chan, L. H. \& Borg, L. E. Boron and lithium isotopic variations in a hot subduction zone-the southern Washington Cascades. Chem. Geol. 212, 101-124 (2004). 
50. Sadofsky, S. J., Portnyagin, M., Hoernle, K. \& van den Bogaard, P. Subduction cycling of volatiles and trace elements through the Central American volcanic arc: evidence from melt inclusions. Contrib. Mineral. Petrol. 155, 433-456 (2008).

51. Hermann, J. \& Spandler, C. Sediment melts at sub-arc depths: an experimental study. J. Petrol. 49, 717-740 (2008).

52. Gerya, T. A. \& Yuen, D. A. Rayleigh-Taylor instabilities from hydration and melting propel 'cold plumes' at subduction zones. Earth Planet. Sci. Let. 212, 47-62 (2003).

53. Tonarini, S., Leeman, W. P. \& Leat, P. T. Subduction erosion of forearc mantle wedge implicated in the genesis of the South Sandwich Island (SSI) arc: evidence from boron isotope systematics. Earth Planet. Sci. Lett. 301, 275-284 (2011).

54. Righter, K. A comparison of basaltic volcanism in the Cascades and western Mexico: Compositional diversity in continental arcs. Tectonophysics 318, 99-117 (2000)

55. Leeman, W. P., Smith, D. R., Hildreth, W., Palacz, Z. \& Rogers, N. Compositional diversity of late Cenozoic basalts in a transect across the southern Washington Cascades: Implications for subduction zone magmatism. J. Geophys. Res. 95, 19561-19582 (1990).

56. Leeman, W. P., Lewis, J. F., Evarts, R. C., Conrey, R. M. \& Streck, M. J. Petrologic constraints on the thermal structure of the Cascades arc. J. Volcanol. Geotherm. Res. 140, 67-105 (2005).

57. Alasonati Tasárová, Z. Towards understanding the lithospheric structure of the southern Chilean subduction zone $\left(36^{\circ} \mathrm{S}-42^{\circ} \mathrm{S}\right)$ and its role in the gravity field. Geophys. J. Int. 170, 995-1014 (2007).

58. Hackney, R. et al. in The Andes: Active Subduction Orogeny (eds Oncken, O. et al.) 355-374 (Springer-Verlag, Berlin, 2006).

59. Moreno, M. et al. Heterogeneous plate locking in the South-Central Chile subduction zone: Building up the next great earthquake. Earth Planet. Sci. Lett. 305, 413-424 (2011).

60. Gerya, T. A. Introduction to Numerical Geodynamic Modelling 359 (Cambridge University Press, 2010).

61. Schmeling, H. et al. A benchmark comparison of spontaneous subduction models-towards a free surface. Phys. Earth Planet. Int. 171, 198-223 (2008).

62. Carlson, R. \& Miller, D. Mantle wedge water contents estimated from seismic velocities in partially serpentinized peridotites. Geophys. Res. Lett. 30, 1250 (2003).

63. Connolly, J. A. D. Computation of phase equilibria by linear programming: a tool for geodynamic modeling and its application to subduction zone decarbonation. Earth Planet. Sci. Lett 236, 524-541 (2005).
64. Sizova, E., Gerya, T. A., Brown, M. \& Perchuk, L. L. Subduction styles in the Precambrian: insight from numerical experiments. Lithos 116, 209-229 (2010).

65. Becker, J. J. et al. Global bathymetry and elevation data at 30 arc seconds resolution: SRTM30_PLUS. Marine Geodesy 32, 355-371 (2009).

66. Hayes, G. P., Wald, D. J. \& Johnson, R. L. Slab1.0: a three-dimensional model of global subduction zone geometries. J. Geophys. Res. 117, B01302 (2012).

67. McCrory, P., Blair, J. L., Oppenheimer, D. H. \& Walter, S. R. Depth to the Juan de Fuca slab beneath the Cascadia subduction margin-a 3-D model for sorting earthquakes. USGS Data Series 91 (2004).

\section{Acknowledgements}

All numeric computations were performed at the Computational Geodynamics Laboratory - CGEO supercomputing facility (Horus). Financial support for this study was provided by PAPIIT IN110412, PAPIIT IN109613 and CONACyT 132265 research grants.

\section{Author contributions}

V.C.M. and T.G. set up the numeric model, and V.C.M., W.P.L. and M.M. took the lead in writing the manuscript. W.P.L. provided the geochemical data and prepared the plots V.C.M. and M.M. performed the numeric modelling on Horus supercomputer. T.G., V.C.M. and G.Z. post-processed the modelling results, prepared the figures and provided comments and revisions.

\section{Additional information}

Supplementary Information accompanies this paper at http://www.nature.com/ naturecommunications

Competing financial interests: The authors declare no competing financial interests.

Reprints and permission information is available online at http://npg.nature.com/ reprintsandpermissions/

How to cite this article: Manea, V. C. et al. Subduction of fracture zones controls mantle melting and geochemical signature above slabs. Nat. Commun. 5:5095 doi: 10.1038/ncomms6095 (2014). 